Nig. J. Biotech. Vol. 33 (2017) 41-48

ISSN: 01891731

Available online at

http://www.ajol.info/index.php/njb/index

and www.biotechsocietynigeria.org

DOI: https://dx.doi.org/10.4314/v33i1.6

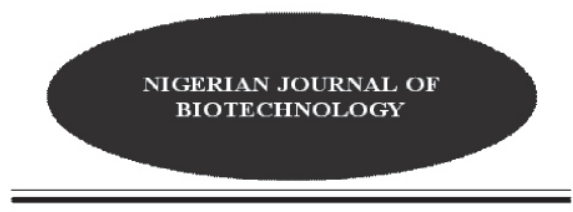

\title{
Molecular detection and characterisation of Horsegram Yellow Mosaic Virus (HgYMV) infecting Lima bean (Phaseolus lunatus) in India
}

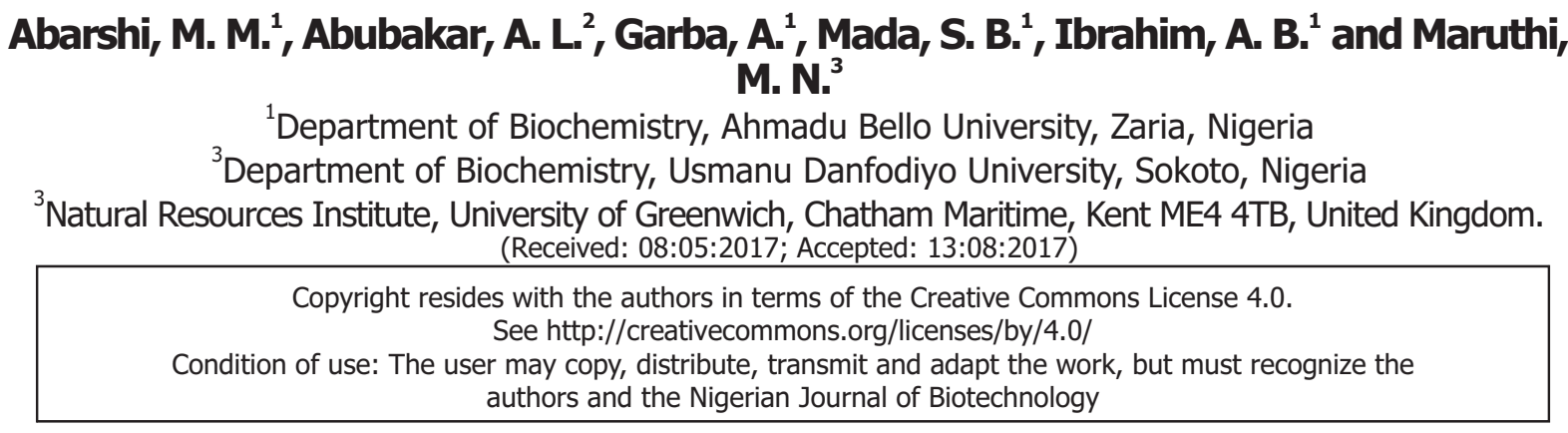

\section{Abstract}

The present study developed a PCR protocol using designed sequence virus-specific sets of primers (HYMV-A1500F \& HYMV-A1500R and D-HYMV-B2200F \& D-HYMV-B2200R) for the amplification of the complete DNA-A and DNA-B components of lima bean isolate of Horsegram yellow mosaic virus (HgYMV-Lb). The PCR products were cloned and sequenced. The nucleotide sequences of HgYMV-Lb was determined and compared with those of other whitefly-transmitted geminiviruses. The length of the single-stranded DNA-A and DNA-B components of HgYMV-Lb were 2735 and 2670 nucleotide, respectively. The DNA-A sequences were found most similar to the corresponding sequences of begomovirus species infecting legumes by up to $97 \%$ nucleotide identity. The DNA-B sequences were most similar to isolates of both Mungbean yellow mosaic virus and Mungbean yellow mosaic India virus at approximately $70 \%$ nucleotide identity. The genome organisation of HgYMV-Lb was also similar to that of a typical begomovirus bipartite genome. The DNA-A component has six Open Reading Frames (AV1/CP, AV2, AC1/REP, AC2/TrAP, AC3/REn, and AC4) and DNA-B has two (BC1 and BV2). The number, size and arrangement of the Open Reading Frames in the genome were similar to the Old world begomoviruses. In addition, phylogenetic analysis of DNA-A sequence clustered HgYMV-Lb into a group of legume-infecting begomoviruses from the Indian sub-continent, particularly with Mungbean yellow mosaic virus. Based on DNA-B sequences, HgYMV-Lb was clustered into the group with Mungbean yellow mosaic virus infecting soybean in Madurai (MYMV-Sb:Mad) and Mungbean yellow mosaic India virus in Bangladesh (MYMIV-BD:Yb). Thus, based on the PCR and sequence analysis, the association of a bipartite begomovirus with lima bean showing symptoms yellow mosaic disease in India was confirmed. Also, it was identified that the begomovirus was a novel isolate of previously described Horsegram yellow mosaic virus.

Keywords: Horsegram, Lima bean, Yellow mosaic virus, Begomovirus

Correspondence: muawiyam@yahoo.co.uk, +234(0)8069517779

\section{Introduction}

Lima bean (Phaseolus lunatus) is a pulse legume crop, grown for its seed which is eaten as vegetable. It is also commonly known as the butter bean. Lima bean originated in Peru and has been grown by the people in the region since 6000 B.C. lima beans are found in varieties of colors, white seeds are the most common, but black, red, orange and variously mottled seeds are also known (Santos et al., 2008). The beans are common in seasonally wet and dry climates (Gobertson, 2004). It's grown as vines that grow over surrounding vegetation in the wet season and then die back in the dry season. Domestication of lima bean appears to have taken place twice. The earlier domestication occurred in northwestern South America and produced the large lima bean varieties (Gobertson, 
2004). Sieve bean, butter bean, and baby lima bean varieties originate from second domestication which occurred in Central America, probably in Guatemala although the earliest archaeological evidence is from Mexico dated to $800 \mathrm{AD}$ (Gobertson, 2004). However, Lima beans are now grown all over the world and eaten as either cooked or as fresh vegetable.

Lima beans are rich in fiber which helps to eliminate cholesterol from the body (Gobertson, 2004). The beans are a good source of potassium, iron, copper and manganese. As it contain high potassium and low sodium, thus help reduce blood pressure (Kathirvel and Kumudha, 2011). Lima beans are low in fat, and in combinations with grains, the beans supply high quality protein which provides a healthy alternative to meat or other animal proteins. The beans also contain protease inhibitors which frustrate the development of cancerous cells in the humans (Collins, 2007; Kathirvel and Kumudha, 2011). The wild Lima bean seeds have high levels of glucosides which breakdown to toxic hydrocyanic acid when the seeds are bruised or chewed. However, modern domesticated varieties, particularly those with white seeds have minimal quantities of hydrocyanic acid and are not toxic. Cooking in boiling water also destroys the cyanogens (Gobertson, 2004).

Lima bean plant is affected by several bacterial and nematode diseases including; bacterial blight (Xanthomonas campestris pv. phaseoli), fusarium root rot (Fusarium solani), web blight (Rhizoctonia solani), anthracnose (Colletotrichum spp.,) downy mildew (Phytophthora phaseoli), root knot nematode (Meloidogyne incognita). Two viral diseases are also reported to infect lima bean; namely, lima bean yellow mosaic virus (LYMV) transmitted by whiteflies (Bemisia tabaci Genn.) and lima bean green mottle virus (LBGrMV) transmitted by aphids in tropical and sub-tropical regions (Baudoin, 2006). Yellow mosaic disease affect many legumes are caused by many species of whitefly-transmitted geminiviruses (genus: Begomovirus, family: Geminiviridae), such as Mungbean yellow mosaic virus (MYMV), Mungbean yellow mosaic India virus (MYMIV), Dolichos yellow mosaic virus (DoYMV) and Horsegram yellow mosaic virus (HgYMV). These viruses cause yield losses to a number of important pulse crops including horsegram and lima bean in the tropical and sub-tropical regions. The disease incidences can be high, often ranging from $50-100$ percentdepending on the cultivar susceptibility and time of infection (Govindu, 1964; Fauquet et al., 2003, Maruthi et al., 2006).
Amongst the viruses, Yellow mosaic virus has been considered as an economically important because of its effect on the growth and yield of many legume species such as Cajanas cajan, Glycine max, hairy indigo (Indigofera hirsute), Macrotyloma uniflorum, Phaseolus lunatus, Phaseolus vulgaris, Vigna mungo and Vigna radiate (Muniyappa et al., 2008). It produces yellow mosaic symptoms and is easily transmitted by whitefly vector Bemisia tabaci (Order Hemiptera, family: Aleyrodidae) (Pant et al., 2001; Maruthi et al., 2006; Qazi et al., 2007). Initially, the symptoms caused by Yellow mosaic virus appear as small yellow specks along the veins and then spread over the leaf and are largely dependent on host species and their susceptibility. The viruses infecting legumes that have been identified by several studies are either bipartite (composed of DNA-A \& DNA-B) or monopartite (composed of DNA-A \& DNA$\beta)$ begomoviruses. Mungbean yellow mosaic virus and Mungbean yellow mosaic India virus are typical bipartite begomoviruses (Pant et al., 2001; Maruthi et al., 2007; Qazi et al., 2007). Thus, Yellow mosaic virus infecting lima bean from India sub-continent has not yet been characterized. The present study developed PCR protocol for HgYMV which infects lima bean that originated from the Indian sub-continent and characterized its genome structure and genome organization, and also established its genetic relationship with other begomoviruses.

\section{Materials and methods}

Sample collection and virus detection

Leaf samples of Lima bean (Phaseolus lunatus) plant showing typical symptoms of begomovirus infection were collected from a farm near Bangalore, Karnataka State, South India. The typical symptoms found in the leaves were diverse and included severe to yellowing, mosaic, veinal chlorosis, down curling, leaf distortion and severe stunting. Samples were brought to the laboratory in plastic bags and stored at $-20^{\circ} \mathrm{C}$. The presence of begomovirus was confirmed by observing symptom expression on leaves and by PCR using degenerate begomovirus Deng $A / B$ primers (Deng et al., 1994) and PAL1c1960/PAL1R 722 primers (Rojas et al., 1992).

\section{Specific Primers design}

The amplified PCR products obtained from degenerate primer sets were cloned and sequenced (Rojas et al., 1992; Maruthi et al., 2007). The sequences obtained were used to design sequence (virus) specific sets of primers for the amplification of the complete DNA$A$ and DNA-B of the begomovirus. The sequences were aligned using either MEGA5 software programme. The primers, HYMV-A1500F \& HYMV-A1500R and HYMV-B 2200F \& D-HYMV-B2200R were designed to amplify full- 
length DNA-A and DNA-B components, respectively (Table 1). All the primers were used at annealing temperatures ranging $52-55^{\circ} \mathrm{C}$.

\section{Extraction of DNA from virus infected leaves}

Total DNA was extracted from leaf tissue collected from lima bean plant showing typical begomovirus leaf symptoms, using cetyltrimethyl ammonium bromide (CTAB) procedure as described by Taylor and Powell (1982) and modified by Maruthi et al. (2002). About $100 \mathrm{mg}$ of leaf tissue was ground thoroughly in a thick-gauged plastic bag using a hand-held ball bearing sample grinder (Bioreba AG, Reinach, Switzerland) and mixed using a wallpaper seam roller in 10 volumes $(1 \mathrm{ml})$ of CTAB buffer ( $2 \%$ CTAB (w/v), $1.4 \mathrm{M} \mathrm{NaCl}, 0.2 \%$ 2-mercaptoethanol (v/v), $20 \mathrm{mM}$ EDTA, $100 \mathrm{mM}$ Tris- $\mathrm{HCl}, \mathrm{pH}$ 8.0). About $750 \mu \mathrm{l}$ of each sample transferred to a $1.5 \mathrm{ml}$ eppendorf tube, mixed and incubated at $60^{\circ} \mathrm{C}$ for 10 minutes. The extract was mixed with an equal volume $(750 \mu \mathrm{l})$ of Phenol:Chloroform:Isoamyl alcohol in a ratio of 25:24:1 (quantity), mixed thoroughly and centrifuged at $12,000 \times \mathrm{g}$ for 10 minutes. The supernatant was transferred to a new $1.5 \mathrm{ml}$ eppendorf tube and nucleic acids were precipitated by adding 0.6 volumes $(300 \mu \mathrm{l})$ of ice cold $\left(-20^{\circ} \mathrm{C}\right)$ isopropanol. Samples were then incubated at $-20^{\circ} \mathrm{C}$ for 1 hour and centrifuged at $12,000 \times \mathrm{g}$ for 10 minutes at $4^{\circ} \mathrm{C}$. The pellet was washed in $0.5 \mathrm{ml} 70 \%$ ethanol, centrifuged for 5 minutes and vacuum-dried for 5 minutes in a Spin Vac. The pellet was dissolved in 1XTE buffer and stored at $-20^{\circ} \mathrm{C}$ till use.

\section{Amplification of complete genome of HgYMV in infected leaves}

All the DNA samples were subjected to series of PCRs, with primers that directly amplify specific regions (AV1/CP, AV2, AC1/Rep, AC2/TrAP, AC3/REn, and AC4 for DNA-A and BV1/NSP and BC1/MP for DNA-B) in the genome of the begomovirus. PCR was performed using Red hot polymerase kit (Thermo Fisher Scientific Ltd., Loughborough, UK) following manufacturer's instructions. The procedure was carried out in a total volume of $25 \mu$ containing $1 \mu \mathrm{l}$ of total DNA and $24 \mu \mathrm{l}$ reaction mixture consisting of $\mathrm{MgCl}_{2}(25 \mathrm{mM})$, forward and reverse primers $(20 \mu \mathrm{M}), 10 x$ PCR buffer, dNTPs (20 $\mathrm{mM})$, and $(5 \mathrm{U} / \mu \mathrm{l})$ Taq polymerase. The primer sets HYMV-A1500F \&HYMV-A1500R and D-HYMV-B 2200F \& D-HYMV-B2200R were used to amplify full-length DNA$A$ and DNA-B components, respectively. The PCR cycling conditions included an initial incubation at $94^{\circ} \mathrm{C}$ for 1 minute, followed by 35 cycles of $94^{\circ} \mathrm{C}$ for 30 seconds, $52^{\circ} \mathrm{C}$ for 30 seconds and $72^{\circ} \mathrm{C}$ for 1 minute, and ending with a final extension step of $720 \mathrm{C}$ for 10 minutes.

Table 1: Primers used for the polymerase chain reaction-amplification of Horsegram yellow mosaic virus (HgYMV)

\begin{tabular}{|c|c|c|c|c|c|}
\hline Primer name & Primer sequence $\left(5^{\prime}-3^{\prime}\right)$ & $\begin{array}{c}\text { Annealing site on } \\
\text { DNA-A }\end{array}$ & $\begin{array}{l}\text { Size of } \\
\text { PCR } \\
\text { products }\end{array}$ & $\begin{array}{l}\text { Primer } \\
\text { specificity }\end{array}$ & Reference \\
\hline Deng A & TAATATTACCKGWKGVCCSC & 1 & 530 bp & Degenerate, & Deng et al., 1994 \\
\hline Deng B & TGGACYTTRCAWGGBCCTTCACA & 530 & & & \\
\hline $\begin{array}{l}\text { PAL1c1960 } \\
\text { PAL1v722 }\end{array}$ & $\begin{array}{l}\text { ACNGGNAARACNATGTGGGC } \\
\text { GGNAARATHTGGATGG }\end{array}$ & $\begin{array}{c}1960 \\
722\end{array}$ & $1.4 \mathrm{~kb}$ & $\begin{array}{l}\text { Degenerate, } \\
\text { begomovirus }\end{array}$ & Rojas et al., 1992 \\
\hline HYMV-A $1500 \mathrm{~F}$ & CTGCAGTGATGTTGTCCCCKG & 1500 & $2.8 \mathrm{~kb}$ & HgYMV & \\
\hline HYMV-A 1500R & CTGCAGCTCAACTCAGGARTGG & 1500 & & & \\
\hline D_HYMV-B2200F & GAATTCATGAATAAATGGCCG & 2200 & $2.7 \mathrm{~kb}$ & HgYMV & \\
\hline D_HYMV-B2200R & GAATTCATAATTCCCTTGTCATG & 2200 & & & \\
\hline
\end{tabular}

Cloning and sequencing of the complete genome of HgYMV

The PCR products obtained from the amplification of the full-length DNA-A (2.8 kb) using HYMV-A1500F \& HYMV-A1500R and DNA-B (2.7 kb) components of HgYMV-Lb usingD-HYMV-B 2200F \& D-HYMV-B2200R were cloned into pGEMT Easy vector (Promega, UK) and transformed to bacterial strains Escherichia coli (Promega, UK). The services of a commercial company (MRC Gene services Ltd, Cambridge, UK) were used for plasmids DNA sequencing. For each sample two clones were sequenced in both directions using T7 and SP6 primers. The sequences were edited and aligned using the software package MEGA5 (Tamura et al., 2007). BLAST search analysis was carried out to confirm the identity of the sequences. Maximum parsimony analysis and heuristic search were used to generate the most parsimonious phylogenetic tree. The full-length DNA-A and DNA-B sequences of the two isolates from DNA-A component and the three isolates from DNA-B were compared with those reference Begomovirussequences obtained from the National Center for Biotechnology Information (NCBI) database. 


\section{Results}

Total DNA extraction from virus infected leaves

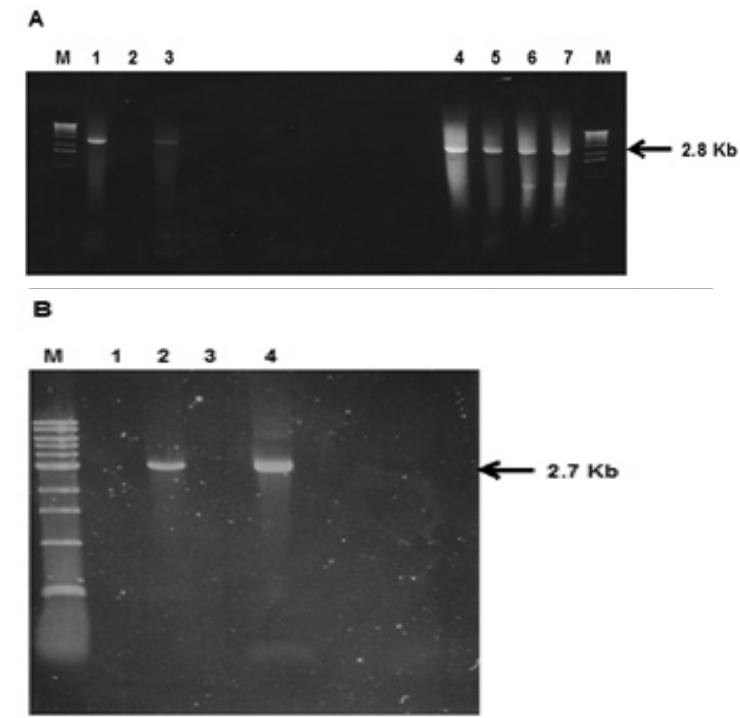

Total DNAs were extracted from leaves of lima bean. The modified DNA extraction protocol provided enough quantity and quality of DNAs sufficient to carry out over 100 PCR reactions. However, initially, there were some problems in amplifying viral DNA fragments. This may be due to various reasons including the presence of impurities and inhibitors in DNA samples. Therefore, the DNA extraction protocol was modified by replacing Phenol:Chloroform:Isoamyl alcohol (25:24:1) with Chloroform:Isoamyl alcohol (24:1), which produced DNAs with less impurities.

Genome organisation of HgYMV-Lb

The full-length DNA-A and DNA-B component PCR products of HgYMV-Lb were 2735 and 2670 nucleotides, respectively (Fig. 1). A CR was identified in DNA-A and DNA-B sequences of the virus. The common region (CR) contained the nona-nucleotide sequence TAATATTAC that is conserved in the stem loop of all begomoviruses, which has the DNA nicking site for the initiation of replication. The total numbers of open reading frames (ORFs) in begomoviruses predicted are identified for each virus component (Fig. 2). DNA-A component was predicted to encode six genes (AV1/CP, AV2, AC1/Rep, AC2/TrAP, AC3/REn, and AC4) and DNA-B component to encode two genes (BV1/NSP and BC1/MP) (Table 2). The genes encoded for both the virion and complementary sense strands with their size and arrangements were typical of previously reported HgYMV and other begomoviruses.

Table 2: Genome organisation of Horsegram yellow mosaic virus infecting Lima bean (HgYMV-[Lb]).

\begin{tabular}{llll}
\hline $\begin{array}{l}\text { Open reading frame } \\
\text { (ORF) gene }\end{array}$ & Nucleotide positions & No. of nucleotides & No. of amino acids \\
\hline AV1/CP & $305-1078$ & 774 & 257 \\
AV2 & $145-495$ & 351 & 116 \\
AC1/Rep & $1527-2615$ & 1089 & 362 \\
AC2/TrAP & $1220-1627$ & 408 & 135 \\
AC3/REn & $1075-1479$ & 405 & 134 \\
AC4 & $2165-2458$ & 294 & 97 \\
BV1/NSP & $428-1198$ & 771 & 256 \\
BC1/MP & $1233-2129$ & 897 & 298 \\
Unknown ORF & $533-973$ & 441 & 146 \\
\hline
\end{tabular}


Full-length DNA-A and DNA-B
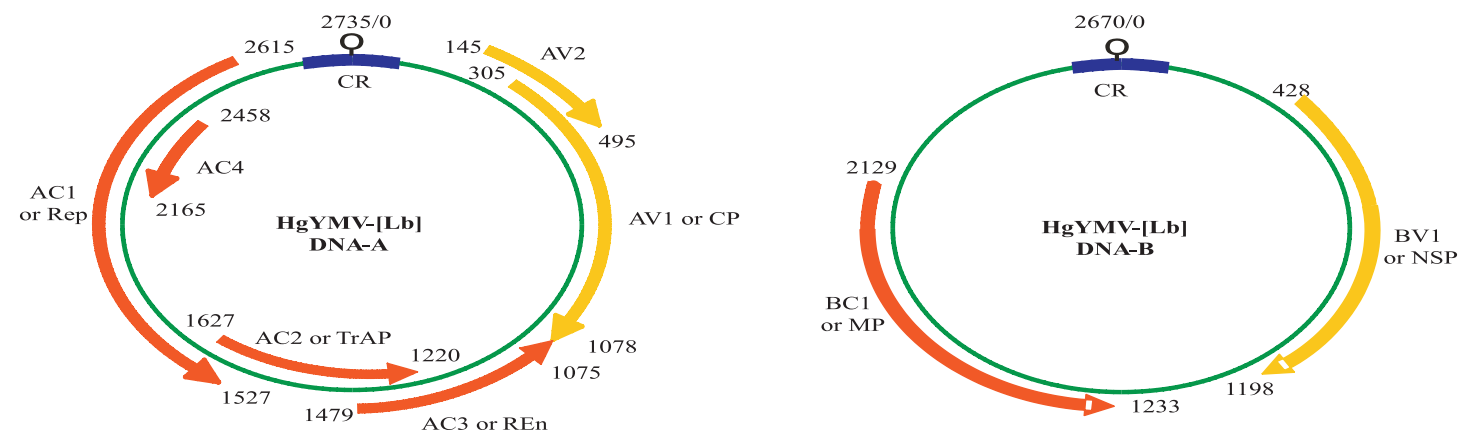

Fig. 2: Genome maps of Horsegram yellow mosaic virus from Lima bean (HgYMV-[Lb]). The numbering of nucleotides on the maps follows the geminivirus convention. The numbers (nucleotide positions) referred to

Genetic variability of HgYMV-Lb with other Begomoviruses

Sequences obtained were identified (closest homology sequence) using BLAST search. The DNA-A sequences were found most similar to the corresponding sequences of begomovirus species infecting legumesby up to $97 \%$ nucleotide identity. The DNA-B sequences were most similar to isolates of both Mungbean yellow mosaic virus and Mungbeanyellow mosaic India virus by approximately $70 \%$ nucleotide identity. The nucleotide sequences for the complete DNA-A and DNA-B of HgYMV-[Lb] were compared with selected begomovirusesfrom NCBI database. The phylogenetic tree obtained using the DNA-A nucleotide sequences showed two clusters (Fig. 3), begomoviruses infecting legumes in Asia (Mungbean yellow mosaic India viruses, Mungbean

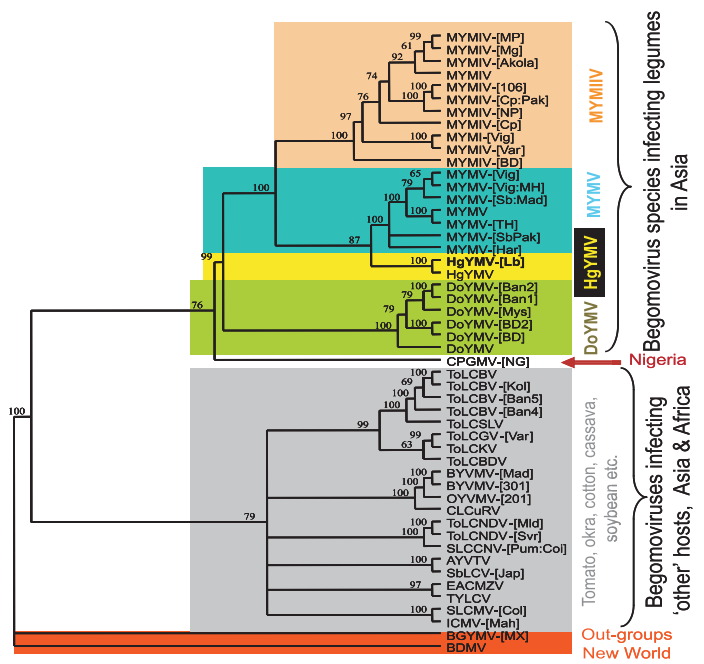

Fig. 3: Dendrogram showing the relationship of HgYMV-Lb to other geminiviruses based on DNA-A nucleotide sequences. Vertical distances are arbitrary and the horizontal distances are proportional to mutational changes in the sequences. Numbers at nodes indicate percent bootstrap scores using 100 replicates. yellow mosaic viruses), begomoviruses infecting other hosts in Asia and Africa (Viruses infecting tomatoes, cassava, okra, soyabean, and cotton), in which HgYMV$\mathrm{Lb}$ was grouped in HgYMV isolates. The branch tree of $\mathrm{HgYMV}$ isolates showed less sequence variation among these isolates. The branching out of different MYMIV and MYMV isolates suggested that these were entirely different viruses. Similar groupings were also observed in phylogenetic tree obtained using DNA-B nucleotide sequences except that HgYMV-Lb clustered into group with Mungbean yellow mosaic virus infecting soybean in Madurai (MYMV-Sb:Mad) and Mungbean yellow mosaic India virus in Bangaladesh (MYMIV-BD:Yb)(Fig. 4). From the results obtained, it was evident that the virus associated with yellow mosaic disease of lima bean is more closely related to other HgYMV isolates from different regions, rather than MYMIV and MYMV.

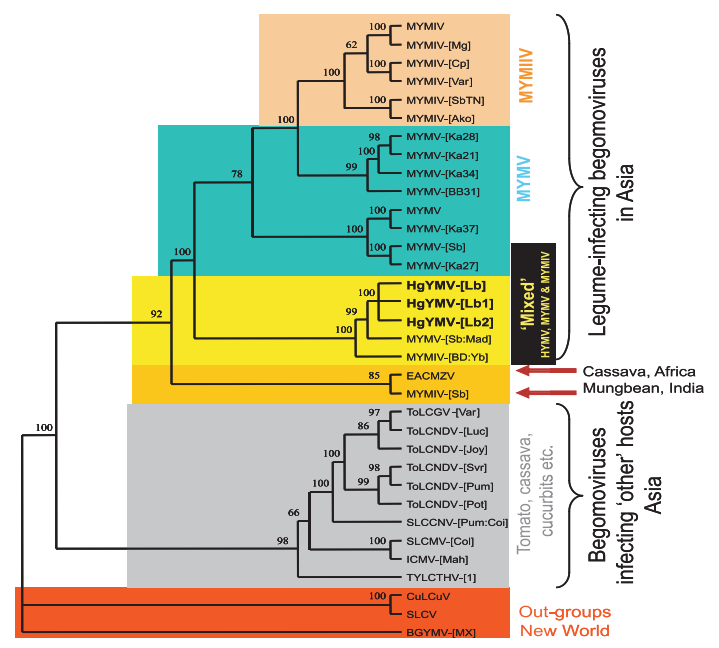

Fig. 4: Dendogram showing the relationship of HgYMV-Lb to other geminiviruses based on DNA-B nucleotide sequences. Vertical distances are arbitrary and the horizontal distances are proportional to mutational changes in the sequences. Numbers at nodes indicate percent bootstrap scores using 100 replicates. 


\section{Discussion}

The present study was performed to develop a diagnostic PCR protocol for a begomovirus (HgYMV-Lb) infecting lima bean of Indian sub-continent, sequence the complete genome of HgYMV-Lb as well as to establish its genetic relationship with other begomoviruses. The horsegram yellow mosaic virus was detected successfully using the degenerate primers in lima bean of the four samples. The inability to detect the virus in the remaining samples could be attributed to the presence of inhibitors such as polyphenols in the DNA samples that could result in a negative PCR. Although this is unlikely because the DNA samples were diluted serially to reduce the effect of inhibitors and PCR protocol was optimized under several conditions. In addition, there was also the possibility that the samples collected based on symptoms phenotype can be caused by other pathogens, which are undetectable in PCR technique using begomovirus-specific primers. Degenerate primers (Deng $A / B$ and PAL1c1960/PAL1R 722) were used for the amplification of the begomovirus DNA. The PCR products of $\sim 530 \mathrm{bp}$ and $\sim 1.4 \mathrm{~kb}$ were obtained. Our result confirms the use of these primers as effective tool for detection of begomoviruses. Furthermore, the amplified PCR products obtained from degenerate primer sets were cloned and sequenced. The sequences obtained thereafter were used to design sequence (virus) specific sets of primers for the amplification of the complete DNA-A and DNA-B of the begomovirus. The specific primers used for the detection of the virus in the samples have been modified and amended several times in order to provide reliable and robust PCR amplification. With the PCR protocol developed, it is now possible to reliably detect Horsegram yellow mosaic virus in plants infected with yellow mosaic disease. The sequences obtained in the present study were compared with sequences from other begomoviruses deposited in Gene bank. Thus, complete sequences of the DNA-A component and DNA-B component were determined. Similar to the results obtained by previous studies (Padidam et al., 1995; Seal et al., 2006; Qazi et al., 2007), we demonstrated thatthe complete nucleotide sequence analysis indicates each component contained an ORFs found in bipartite begomoviruses. Moreover, the length of the singlestranded DNA-A and DNA-B component of HgYMV[Lb] were 2735 and 2670 nucleotides, respectively.

Sequence comparisons of the complete genomes confirmed that HgYMV-[Lb] belonged to the genus Begomovirus. Interestingly, both the DNA-A and DNA-B sequences were most similar to the corresponding sequences of an isolate described previously for Horsegram yellow mosaic virus by approximately $97 \%$ nucleotide sequences identity (Qazi et al., 2007; Monger et al., 2010; Manjunatha et al., 2015). The data also confirmed that a begomovirus causing yellow mosaic disease in lima bean was an isolate of HgYMV. Our data was in agreement with the result obtained by Rienzieet al. (2016), which reported that the virus was detected by PCR amplification using Deng 540/541 and AV494/AC1048 primers and the primers amplified $\sim 520 \mathrm{bp}$ and $\sim 550$ bp products corresponding to the coat protein gene of the virus. The phylogenetic analysis revealed that the virus associated with Bean yellow mosaic disease was closely related to Horsegram yellow mosaic virus isolate (HgYMV-LK: 09Bean) reported in Sri Lanka (Rienzieet al., 2016).

In addition, our data showed that the genome organisation of HgYMV-Lb was most similar to that of a typical begomovirus bipartite genome reported by previous studies (Qazi et al., 2007; Monger et al., 2010; Rienzieet al., 2016). The DNA-A component has six ORFs (AV1/CP, AV2, AC1/Rep, AC2/TrAP, AC3/REn, and AC4) and DNA-B has two ORFs (BC1 and BV2). The number, size and arrangement of the ORFs in the genome were similar to the old world begomoviruses reported by previous studies (Rajeshwari et al., 2005; Monger et al., 2010; Rienzie et al., 2016). The phylogenetic analysis based on the complete DNA-A or DNA-B components showed that this begomovirus was placed into the group of legumes-infecting begomoviruses from Indian sub-continent. Furthermore, the phylogenetic analysis of DNA-A sequence clustered isolates of HgYMV into a group of legume-infecting begomoviruses from Indian subcontinent, particularly more closely with Mungbean yellow mosaic virus (MYMV). DNA-B sequence was clustered into group with Mungbean yellow mosaic virus infecting soybean in Madurai (MYMV-[Sb:Mad])and Mungbean yellow mosaic indian virus in Bangaladesh (MYMV-[BD:Yb]).The present finding was consistent with the previous studies, which showed predictable relatedness of HgYMV and MYMV (Qazi et al., 2007; Manjunatha et al., 2015) and MYMIV (Manjunatha et al., 2015; Rienzieet al., 2016).

In conclusion, the PCR analysis with degenerate and virus specific primers established that a bipartite begomovirus was associated with lima bean yellow mosaic disease, and was named as HgYMV-Lb. The genome structure and organisation of HgYMV-[Lb]) indicates the genetic relationship with old world begomoviruses and it was identified as an isolate/strain of HgYMV based on DNA sequence analysis.

\section{Acknowledgment}

No funding support for this study, rather all facilities/consumables were provided by the Natural 
Resources Institute, University of Greenwich, United Kingdom.

\section{Reference}

Baudoin, J.P. (2006). Phaseolus lunatus L. In M. Brink, G. Belay, ed: Cereals and Pulses. PROTA (Plant Resources of Tropical Africa) Wageningen, Netherlands, 1: 158-164.

Collins, A. (2007). Diet nutrition: Lima beans. http://www.annecollins.com/diet_foods/Limabean s.htm.

Deng, A., McGrath, P. F., Robinson, D. J. and Harrison, B. D. (1994). Detection and differentiation of Whitefly transmitted Geminiviruses in Plants and Vector insects by the Polymerase Chain Reaction with Degenerated primers. Ann. Appl. Biol.125: 327-336.

Fauquet, C. M., Bisaro, D. M., Briddon, R. W., Brown, J. K., Harrison, B. D., Rybicki, E.

P.,Stenger, D. C. and Stanley, J. (2003). Revision of Taxonomic Criteria for speciesdemarcation in the family Geminiviridae and an updated list of Begomovirus species. Arch. Virol. 148: 405-421.

Gobertson, H. G. (2004). Phaseolus lunatus (Lima bean, Sieva bean, Butter bean). Iziko Museums of C a p e $\mathrm{T}$ o $\mathrm{w} \mathrm{n}$. http://www.museums.org.za/bio/plants/fabaceae/ Phaseolus_lunatus.htm.

Govindu, H. C. (1964). A review on virus diseases of crop plants. Information pamphlet

No.2 (Research series). Directorate of Agriculture, Bangalore. p.13.

Kathrivel, P. and Kumudha, P. (2011). A comparative study on the Chemical composition of Wild and Cultivated Germplasm of Phaseolus lunatus L. Int. J. App. Bio. Phatm.Techn.2(4): 296304.

Manjunatha N., NoorullaHaveri, N., Reddy, B. A. and Hurakadli, S. (2015). Molecular Detection and Characterization of Virus Causing Yellow Mosaic Disease of Redgram (Cajanus cajan L.) in Karnataka. Int. J. Pure App. Biosci. 3(4): 258-264

Maruthi, M. N., Colvin, J., Seal, S., Gibson, G., Cooper, J. (2002). Co-adaptation between Cassava Mosaic Geminiviruses and their local Vector Populations. Virus Res. 86: 71-85.

Maruthi, M. N., Manjunatha, B., Rekha, A. R.,
Govindappa, M. R., Colvin, J. and Muniyappa, V. (2006). Dolichos Yellow Mosaic Virus Belongs to a Distinct Lineage of Old World Begomoviruses; its Biological and Molecular Properties. Ann. Appl. Biol.149: 187-195.

Maruthi,M.N., Rekha, A.R., Mirza, S.H., Alam, S. N. and Colvin, J. (2007). PCR-based Detection and Partial Genome Sequencing indicate high Genetic Diversity in Bangladeshi Begomoviruses and their Whitefly Vector, Bemisia tabaci. VirusGenes, 34(3):373-385.

Monger, W.A., Harju, V., Nixon, T., Bennett, S., Reeder, R., Kelly, P. and Ariyarathne, H.M. (2010). First report of Horsegram Yellow Mosaic virus infecting Phaseolus vulgaris in Sri Lanka. New Dis. Rep.21: 16.

Muniyappa, V., Rajeshwari, R., Bharathan, N., Reddy, D. N. R. and Nolt, B. L. (2008). Isolation and characterization of a geminivirus causing yellow mosaic disease of horsegram (Macrotylomauniflorum [Lam.] Verdc.) in India. J. Phytopathol. 119: 81-87.

Padidam, M., Beachy, R.N. and Fauquet, C.M. (1995) Classification and identification of Geminiviruses using Sequence comparisons. J. Gen. Virol. 76: 249-263.

Pant, V., Grupta, D., Roy Choudhury, N., Malathi, V. G., Varma, A. and Mukherjee, S. K. (2001). Molecular Characterisation of the Rep protein of the Blackgram isolate of Indian Mungbean Yellow Mosaic Virus. J. Gen. Virol. 82: 2559-2567.

Qazi, J., Ilyas, M., Mansoor, S. andBriddon, R.W. (2007). Legume Yellow Mosaic Viruses: Genetically isolated Begomoviruses. Mol. Plant. Pathol. 8: 343-348.

Rajeshwari, R., Reddy, R.V.C., Maruthi, M.N., Colvin, J., Seal, S. E. and Muniyappa V. (2005). Host range, Vector relationships and Sequence comparison of a Begomovirus infecting Hibiscus in India. Ann. Appl. Biol. 147(1): 15-25.

Rienzie, K. D. R. C., Wickramaarachchi, W.A.R.T., De Costa, D.M. and. Wijesooriya, W.M.G.U (2016). Molecular Detection and Characterisation of Begomovirus causing Bean Yellowing Disease in Sri Lanka. J. Natn. Sci. Foundation 44 (3): 249-255.

Rojas, M. R., Gilbertson, R. L., Russell, D. R., Maxwell, D. P. (1993). Use of Degenerate Primers in the Polymerase Chain Reaction to Detect Whitefy-transmitted Geminiviruses. Plant Dis. 77: 340-347.

Santos, J.O., Araujo, A.S.F., Gomes, R.L.F., Lopes, A.C.A. and Figueiredo, M. V. B. ( ( 20008 ). Rhizobia-Phaseoluslunatus Symbiosis: Importance and 
Diversity inTropical Soils - A Review.Dyn. Soil Dyn. Plant. 2(2): 56-60.

Seal, S. E., van den Bosch, F. and Jeger, M.J. (2006) Factors Influencing Begomovirus Evolution and their increasing Global Significance: Implications for Sustainable Control. Crit. Rev. Plant Sci. 25: 23-46.

Tamura, K., Dudley, J., Nei, M. and Kumar, S. (2007). MEGA4: Molecular Evolutionary Genetics Analysis (MEGA) Software version 4.0. Mol. Biol. Evol. 24(8): 1596-1599.

Taylor, N. and Powell, A. (1982). Isolation of Plant DNA and RNA. Focus 4:4-6. 